\title{
Establishment of a novel clear cell sarcoma cell line (Hewga-CCS), and investigation of the antitumor effects of pazopanib on Hewga-CCS
}

Hidetatsu Outani ${ }^{1}$, Takaaki Tanaka ${ }^{1}$, Toru Wakamatsu' ${ }^{1}$, Yoshinori Imura', Kenichiro Hamada ${ }^{1}$, Nobuhito Araki ${ }^{2}$, Kazuyuki Itoh ${ }^{3}$, Hideki Yoshikawa ${ }^{1}$ and Norifumi Naka ${ }^{1,3^{*}}$

\begin{abstract}
Background: Clear cell sarcoma (CCS) is a therapeutically unresolved, aggressive, soft tissue sarcoma (STS) that predominantly affects young adults. This sarcoma is defined by $\mathrm{t}(12 ; 22)(q 13 ; q 12)$ translocation, which leads to the fusion of Ewing sarcoma gene (EWS) to activating transcription factor 1 (ATF1) gene, producing a chimeric EWS-ATF1 fusion gene. We established a novel CCS cell line called Hewga-CCS and developed an orthotopic tumor xenograft model to enable comprehensive bench-side investigation for intensive basic and preclinical research in CCS with a paucity of experimental cell lines.

Methods: Hewga-CCS was derived from skin metastatic lesions of a CCS developed in a 34-year-old female. The karyotype and chimeric transcript were analyzed. Xenografts were established and characterized by morphology and immunohistochemical reactivity. Subsequently, the antitumor effects of pazopanib, a recently approved, novel, multitargeted, tyrosine kinase inhibitor (TKI) used for the treatment of advanced soft tissue sarcoma, on Hewga-CCS were assessed in vitro and in vivo.

Results: Hewga-CCS harbored the type 2 EWS-ATF1 transcript. Xenografts morphologically mimicked the primary tumor and expressed S-100 protein and antigens associated with melanin synthesis (Melan-A, HMB45). Pazopanib suppressed the growth of Hewga-CCS both in vivo and in vitro. A phospho-receptor tyrosine kinase array revealed phosphorylation of c-MET, but not of VEGFR, in Hewga-CCS. Subsequent experiments showed that pazopanib exerted antitumor effects through the inhibition of HGF/C-MET signaling.
\end{abstract}

Conclusions: CCS is a rare, devastating disease, and our established CCS cell line and xenograft model may be a useful tool for further in-depth investigation and understanding of the drug-sensitivity mechanism.

Keywords: Clear cell sarcoma, Cell line, Xenograft, Pazopanib, HGF, cMET

\section{Background}

Clear cell sarcoma (CCS) of tendons and aponeuroses is a rare, malignant, soft tissue tumor [1] characterized by melanocytic differentiation, including immunohistochemical positivity for melanocyte specific-microphthalmiaassociated transcription factor (M-MITF), S100 calcium binding protein (S-100), Melan-A, and melanomaassociated antigen human melanoma black 45 (HMB45)

\footnotetext{
*Correspondence: nnaka@ort.med.osaka-u.ac.jp

'Department of Orthopaedic Surgery, Osaka University Graduate School of Medicine, 2-2 Yamadaoka, Suita, Osaka 565-0871, Japan

${ }^{3}$ Department of Biology, Osaka Medical Center for Cancer and Cardiovascular Diseases, 1-3-3 Nakamichi, Higashinari-ku, Osaka 537-8511, Japan

Full list of author information is available at the end of the article
}

[2]. Typically, CCS arises in the extremities of young adults and accounts for approximately $1 \%$ of all soft tissue sarcomas (STSs) [2]. It usually appears as a deepseated, slowly growing mass, and approximately $50 \%$ patients develop lung or nodal metastases [2]. Because CCS is very resistant to conventional chemotherapy and radiation therapy, the 5-year overall survival is reported to be only $30 \%-67 \%$ [3-11]. Cytogenetic analysis of CCS has detected the presence of clonal chromosomal translocation, $\mathrm{t}(12 ; 22)(\mathrm{q} 13 ; \mathrm{q} 12)$, and identified the fusion of the ATF1 and EWS, resulting in the EWS-ATF1 fusion gene $[12,13]$. Several types of fusion transcripts have been described, of which the most common result from 
the fusion of exon 8 of EWS with exon 4 of ATF1 (type 1), followed by the fusion of exon 7 of EWS with exon 5 of ATF1 (type 2) and the fusion of exon 10 of EWS with exon 5 of ATF1 (type 3) [14]. The rarity of the disease makes it difficult to conduct a clinical study to test the efficacy of a novel therapy. Therefore, we thought it was important to develop a CCS experimental model for understanding the molecular determinants of CCS and developing therapeutic strategies.

Pazopanib is a novel, orally available, multitargeted, TKI targeting several tumor and tumor environment factors with high affinity against vascular endothelial growth factor receptor (VEGFR)1, VEGFR2, and VEGFR3 and low affinity against platelet-derived growth factor receptor (PDGFR) $\alpha$, PDGFR $\beta$, fibroblast growth factor receptor (FGFR)1, FGFR2, and stem cell factor receptor (c-Kit) [15]. A phase III trial conducted to assess the efficacy and safety of pazopanib for metastatic STS using placebo as a control demonstrated a statistically significant improvement in progression-free survival [16], leading to approval of this drug for the treatment of advanced STSs as the first molecular targeted agent in Japan. However, in the phase III study, no detailed information about CCS was available, and there have been no reports demonstrating the treatment effects of pazopanib against CCS. To date, a small number of CCS cell lines have been successfully established [17-27], but those harboring disease specific EWS-ATF1 fusion gene and available in both in vitro and in vivo study are quite rare. Thus, we established a new CCS cell line, Hewga-CCS, and investigated the antitumor effects of pazopanib on Hewga-CCS in vitro and in vivo.

\section{Methods}

\section{Establishment of Hewga-CCS}

The clinical course of the patient with CCS was described in the Supplementary Information (Additional file 1: Figure S1). Tumor cells were isolated from surgically resected tissues obtained from excised skin metastatic lesions after the patients provided written informed consent. The study of establishment was conducted in accordance with the guidelines of the Ethics Committee of Osaka Medical Center for Cancer and Cardiovascular Diseases. The tumor tissues were minced and incubated with $1 \mathrm{mg} / \mathrm{mL}$ of collagenase (Sigma-Aldrich, St. Louis, MO, USA) for $1 \mathrm{~h}$ at $37^{\circ} \mathrm{C}$. Cell suspensions were passed through a 40- $\mu \mathrm{m}$ nylon mesh (BD Falcon, Franklin Lakes, NJ, USA), and the tumor cells were cultured in Dulbecco's modified Eagle's medium (DMEM; Life Technologies, Carlsbad, CA, USA) with 10\% fetal bovine serum (FBS; MP Biomedicals, Aurora, OH, USA). The adherent cells were maintained for $>36$ months in culture and passed $>200$ times, which fulfilled the criteria of a cell line. Throughout the establishment of this cell line, the attached cells continuously expressed the EWS-ATF1 transcript (data not shown).

\section{Chromosomal analysis}

Metaphase chromosome spreads from Hewga-CCS cells were prepared according to standard procedures. HewgaCCS cells were treated with $20 \mu \mathrm{g} / \mathrm{ml}$ of colcemide overnight and harvested. After treatment of $0.075 \mathrm{M} \mathrm{KCl}$ for $20 \mathrm{~min}$ at $37^{\circ} \mathrm{C}$, cells were fixed 3 times with methanol and acetic acid (3:1) and fixed cells were spread on slides. Multicolor fluorescence in situ hybridization (M-FISH) was performed using commercially available M-FISH kits (MetaSystems, Altlussheim, Baden-Württemberg, Germany) according to the manufacturer's protocol. Briefly metaphase spreads were hardened $70^{\circ} \mathrm{C}$ for $2 \mathrm{~h}$. After applying M-FISH probes on the metaphase spreads, co-denaturation of target DNA with probe DNA was performed at $70^{\circ} \mathrm{C}$ for $5 \mathrm{~min}$, followed by $72 \mathrm{~h}$ incubation at $37^{\circ} \mathrm{C}$ to allow hybridization of the probes. The slides were then washed twice with $50 \%$ formamide $/ 2 \times$ standard saline citrate (SSC) solution for $20 \mathrm{~min}$ at $37^{\circ} \mathrm{C}, 2 \times \mathrm{SSC}$ for $10 \mathrm{~min}$ at room temperature and $1 \times \mathrm{SSC}$ for $10 \mathrm{~min}$. The slides were then counterstained with 4',6-diamidino-2-phenylindole (DAPI) and mounted. Separate fluorochrome images were captured using a Leica DC 350FX cooled CCD camera (Leica Microsystems, Wetzlar, Hesse, Germany) mounted on a Leica DM600 B microscope using Leica DM600 B software. The images were analyzed using Leica CytoVision (Leica). The chromosomal analyses were examined at passage 110 and 111.

\section{Enzyme-linked immunosorbent assay (ELISA)}

A total of $1 \times 10^{5}$ cells/well were seeded in 6-well plates in triplicate and cultured for $72 \mathrm{~h}$. Quantikine ELISA kits (R\&D Systems, Minneapolis, MN, USA) were used in accordance with the manufacturer's instructions to measure secreted hepatocyte growth factor (HGF) and VEGF levels in supernatants derived from Hewga-CCS or SYO-1, which is a human synovial sarcoma cell line that was kindly provided by Dr. Ozaki (Okayama University, Okayama, Japan).

\section{Genetic analysis}

TRIzol reagent (Life Technologies) was used to purify total RNA. Total RNA $(1 \mu \mathrm{g})$ was used for the reverse transcription reaction with the High Capacity cDNA Reverse Transcription kit (Life Technologies) according to the manufacturer's instructions. EWS-ATF1 cDNA was identified by polymerase chain reaction (PCR) using EWS forward primer 5'-TCC TAC AGC CAA GCT CCA AGT C and ATF1 reverse primer 5'-ACT CGG TTT TCC AGG CAT TTC AC. For sequence analysis, the reverse-transcriptase (RT) PCR-amplified EWS/ATF1 cDNA fragments were analyzed on $1.5 \%$ agarose gels, purified using a Qiagen gel extraction kit (Qiagen, Hilden, Germany), and directly sequenced using the 
dideoxy procedure and an ABI Prism BigDye terminator cycle sequencing ready reaction kit (Life Technologies) with forward or reverse primers (forward ACTGCAA CCTATGGGCAGAC; reverse, CTGATTGCTGGGCAC AAGTA) on an Applied Biosystems Model 373A DNA sequencing system. BLAST software (http://blast.ncbi. nlm.nih.gov/Blast.cgi) was used for computer analysis of sequence data.

\section{Cell proliferation assay}

Hewga-CCS cells were cultured in DMEM with 10\% FBS. A total of $1 \times 10^{5}$ cells/well were seeded in 6 -well plates in triplicate. Cell proliferation was measured by cell counts or by using the CellTiter-Glo Luminescent Cell Viability Assay (Promega, Madison, WI, USA) according to the manufacturer's protocols. Trypan blue exclusion-based methods were used to determine cell counts. These analyses were examined at passage 120 to 130.

\section{Phosphoreceptor tyrosine kinase (RTK) array}

To evaluate the expression of phosphorylated RTKs, a Proteome Profiler Array Kit (R\&D Systems) comprising spotted antibodies for 49 kinase phosphorylation sites was used to perform the phospho-RTK array according to the manufacturer's protocol.

\section{Cell cycle analysis}

Resuspended Hewga-CCS cells $\left(5 \times 10^{5}\right)$ were plated in DMEM with $10 \%$ FBS and grown overnight before treatment with $10 \mu \mathrm{mol} / \mathrm{L}$ of pazopanib or vehicle. After $24 \mathrm{~h}$ of treatment, the cells were collected, washed, and stained with propidium iodide (PI) solution $(25 \mu \mathrm{g} / \mathrm{mL}$ of PI, $0.03 \%$ NP-40, $0.02 \mathrm{mg} / \mathrm{mL}$ RNase A, $0.1 \%$ sodium citrate) for $30 \mathrm{~min}$ at room temperature. A BD FACSCanto II flow cytometer (BD Biosciences, San Jose, CA, USA) was used to analyze the cell cycle.

\section{Western blot analysis}

Cells were scraped and lysed in ice-cold RIPA buffer (Thermo Scientific, Waltham, MA, USA) supplemented with protease/phosphatase inhibitor cocktail (Cell Signaling Technology, Danvers, MA, USA). After centrifugation, the supernatants were collected and a BCA Assay Reagent (Thermo Scientific) was used to determine protein concentrations. Fifty-microgram aliquots of protein were separated by $10 \%$ sodium dodecyl sulfate polyacrylamide gel electrophoresis and transferred onto a PVDF membrane. After blocking with 5\% skim milk in Tris-buffered saline with $0.1 \%$ Tween-20 for an hour, bound proteins were exposed to the following antibodies overnight at $4^{\circ} \mathrm{C}$ : MET (\#8198 rabbit monoclonal; Cell Signaling Technology), p-MET (\#3077 rabbit monoclonal; Cell Signaling Technology), $\beta$-actin (sc-47778 mouse monoclonal; Santa Cruz Biotechnology, Santa Cruz, CA, USA), Akt (\#4691 rabbit monoclonal; Cell Signaling Technology), p-Akt (\#4060 rabbit monoclonal; Cell Signaling Technology), Erk (\#4695 rabbit monoclonal; Cell Signaling Technology), and p-Erk (\#4370 rabbit monoclonal; Cell Signaling Technology). The secondary antibodies used were HRP-conjugated goat anti-rabbit and anti-mouse IgG (GE Healthcare, Little Chalfont, Buckinghamshire, UK). An ECL plus Western Blotting Detection System kit (GE Healthcare) was used to detect western signals.

\section{RNA interference}

Lipofectamine 2000 reagent (Life Technologies) was used according to the manufacturer's instructions to transfect cells with 20-nM small interfering RNAs (siRNAs). Two kinds of siRNAs against MET were purchased from Cell Signaling Technology (\#6618S).

\section{In vivo models}

Hewga-CCS cells $\left(1 \times 10^{7}\right)$ were subcutaneously injected into the flanks of 5-week-old athymic nude mice (BALB/ c nu/nu; SLC, Shizuoka, Japan). Calipers were used to measure tumor size, and tumor volume was calculated according to the formula $\left(a \times b^{2}\right) / 2$, where "a" was the longest diameter and " $\mathrm{b}$ " was the shortest diameter of the tumor. When the tumors reached a volume of palpable size, the mice were randomized and divided into drug-treated and vehicle-treated groups. Pazopanib was kindly provided by GlaxoSmithKline (London, UK), and pazopanib solution was prepared as described previously [15]. Bevacizumab was purchased from Chugai Pharmaceutical Co. Ltd. (Tokyo, Japan). Bevacizumab dissolved in PBS was intraperitoneally injected at $10 \mathrm{mg} / \mathrm{kg}$ concentration $(200 \mu \mathrm{g} /$ mouse $)$ twice a week for the indicated times. All experiments were approved by our institutional animal committee (the Institutional Animal Care and Use Committee of Osaka University Graduate School of Medicine) and institutional biosafety committee (Osaka University Living Modified Organism Experiments Safety Committee).

\section{Histological analysis}

Tumor tissue samples were fixed in $10 \%$ buffered formalin for $24 \mathrm{~h}$ and embedded in paraffin. Hematoxylin and eosin were used to stain $4-\mu \mathrm{m}$ sections, and serial sections were used for immunohistochemical analysis. The primary antibodies used were anti-Ki67 (M7240; Dako, Glostrup, Denmark), anti-S100 (IR50461; Dako), antiHMB45 (N1545; Dako), and anti-Melan-A (IR633; Dako). The Liquid DAB + Substrate Chromogen System (Dako) was used according to the manufacturer's protocol to perform peroxidase staining. An in situ apoptosis detection kit (Takara Bio, Otsu, Japan) was used according to the 

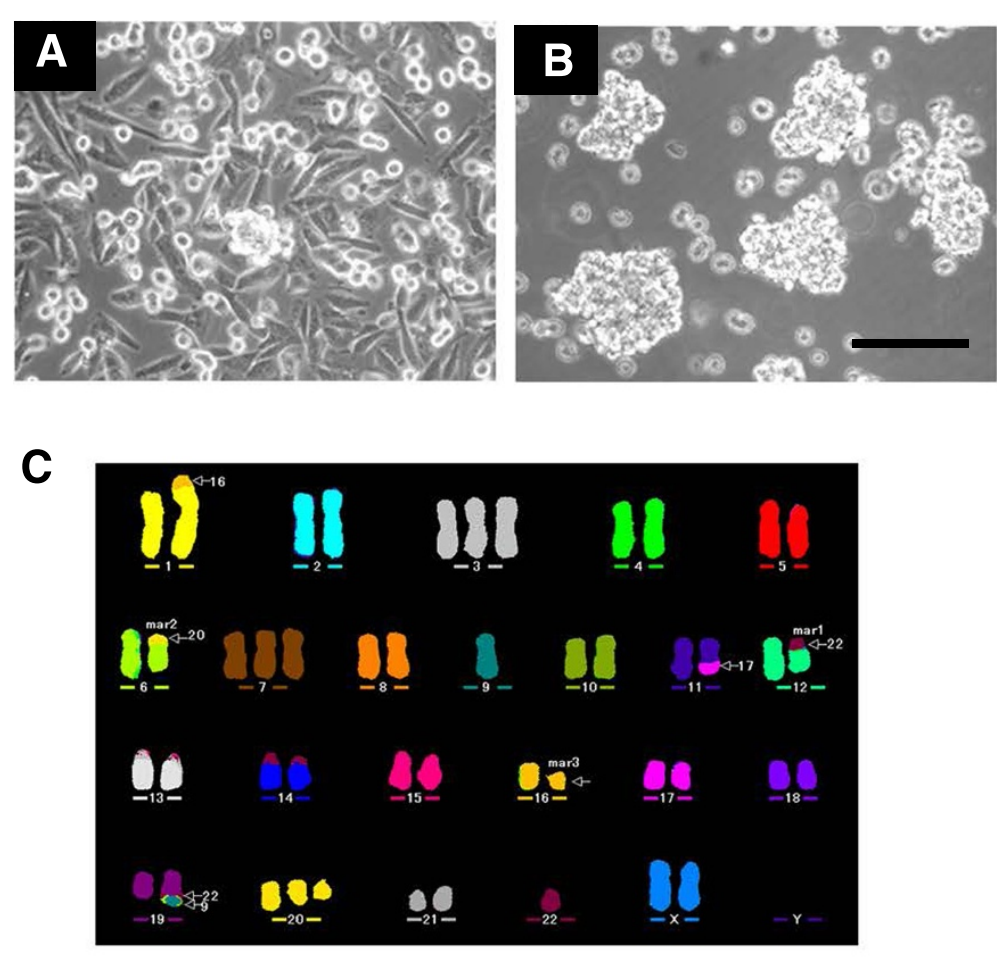

D

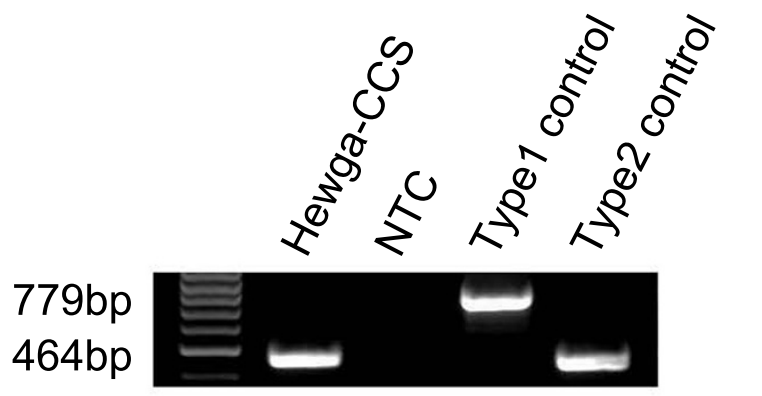

E

\section{Break point}

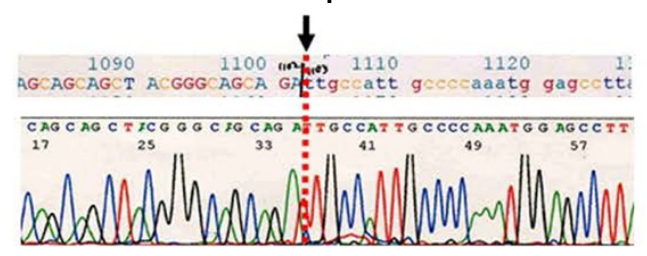

\section{EWS exon7 ATF1 exon5}

Figure 1 Morphology and genetic analysis of Hewga-CCS cells. (A) Phase-contrast image of Hewga-CCS cells cultured in serum-containing medium (DMEM with 10\% FBS). Bar: $100 \mu \mathrm{m}$. (B) Phase-contrast image of Hewga-CCS cells cultured in the low-attachment plates (DMEM with 20\% FBS). Bar: 100 um. (C) Representative karyotype of Hewga-CCS. M-FISH analysis showed 5 recurrent structural chromosomal rearrangements: $\operatorname{der}(1) t(1 ; 16), \operatorname{der}(6) t(6 ; 20), \operatorname{der}(11) t(11 ; 17), \operatorname{der}(12) t(12 ; 22)$, and der(19)t(9;19;22). (D) RT-PCR with EWS forward primer located in exon 7 and ATF1 reverse primer in exon 7 that amplifies a 779 base pair (bp) PCR product in the type 1 EWS-ATF1 transcript and a 464 bp PCR product in the type 2 EWS-ATF1 transcript. Hewga-CCS cells and the type 2 EWS-ATF1 transcript control exhibit a single band of approximately 460 bp in lane 1 and lane 4. No band is present for the negative control (NTC) of distilled water in lane 2. The type 1 EWS/ATF1 transcript control exhibits a single band of approximately $780 \mathrm{bp}$ in lane 3. (E) A partial sequence chromatogram shows that ATF1 exon 5 was fused with EWS exon 7. The arrow indicates the junction of the ATF1 and EWS genes. 

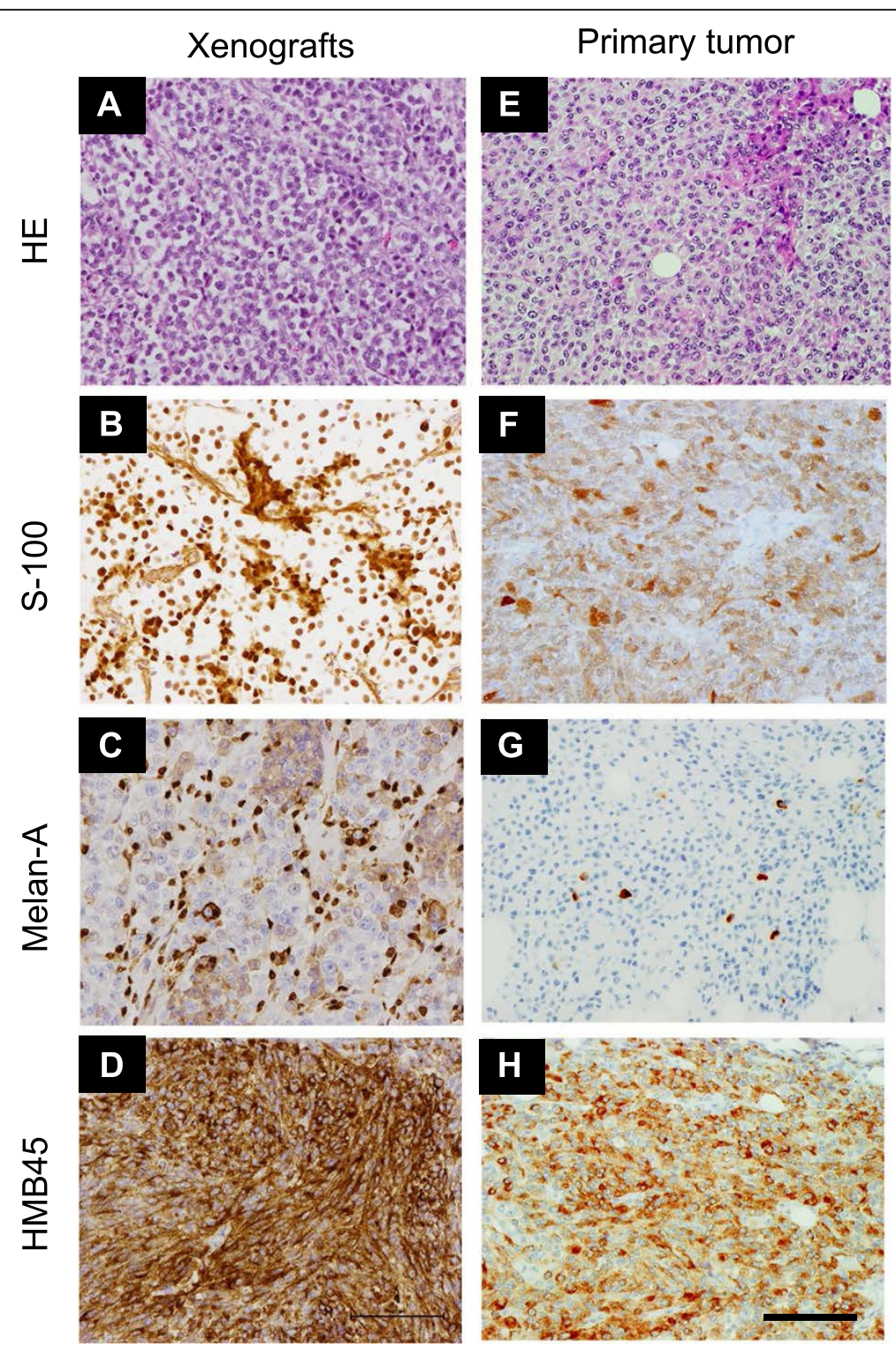

Figure 2 Histological appearance of Hewga-CCS xenografts and primary tumor. (A, E) Hematoxylin/eosin (HE) staining and immunohistochemical staining showing expression of (B, F) S-100 protein, (C, G) Melan-A, and (D, H) HMB45 in the Hewga-CCS xenografts and primary tumor. Bar: $100 \mu \mathrm{m}$.

manufacturer's protocol to perform terminal deoxyribonucleotidyl transferase (TDT)-mediated dUTP-digoxigenin nick end labeling (TUNEL) staining.

\section{Statistical analysis}

The data are shown as averages and standard deviations. Two-tailed Student's $t$-tests were used to compare the data. The immunohistochemical results were statistically analyzed using Fisher's exact test. P-values of $<0.05$ were considered statistically significant.

\section{Results}

\section{Characterization of the Hewga-CCS cell line}

Tumor cells obtained from skin metastatic lesions grew in the form of an adherent monolayer in DMEM with $10 \%$ FBS. Two types of cells were obtained: small round cells and polygonal spindle cells (Figure 1A). The doubling time of the cultured cells was approximately $44 \mathrm{~h}$ (Additional file 2: Figure S2). To examine the capacity of spheroid formation, we cultured the cells on lowattachment dishes with 20\% FBS according to the protocol of our previous study [28]. Under the low- 
A

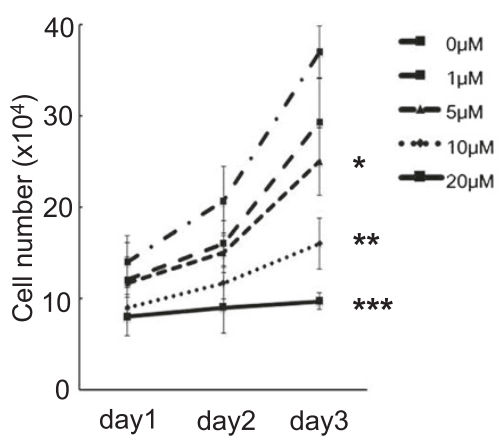

B

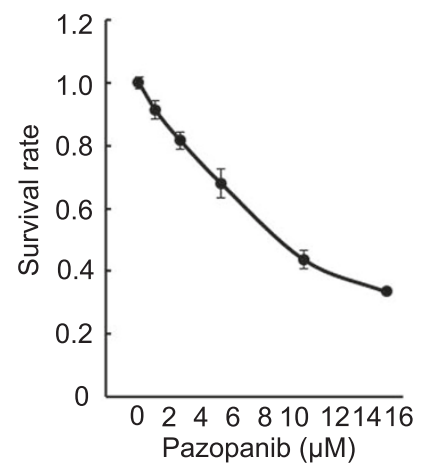

C
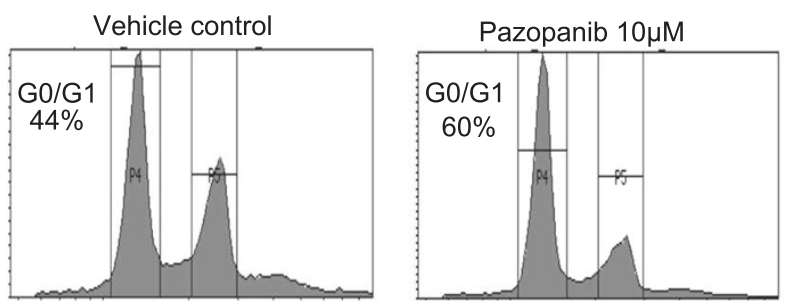

Figure 3 Antitumor effects of pazopanib on Hewga-CCS cells in vitro. (A) Hewga-CCS cells were cultured in serum-containing medium in the absence or presence of $1,5,10$, and $20 \mu \mathrm{M}$ of pazopanib. The cell numbers were counted. Bars: SD. ${ }^{*} P<0.05,{ }^{* *} \mathrm{P}<0.01,{ }^{* * *} \mathrm{P}<0.001$. (B) Hewga-CCS cells were treated with pazopanib $(0,1,2.5,5,10,15 \mu \mathrm{M})$ for $72 \mathrm{~h}$, and the survival rates were assessed by CellTiter-Glo ${ }^{\oplus}$. Bars: SD (C) $10 \mu \mathrm{M}$ of pazopanib- or vehicle-treated Hewga-CCS cells were stained with propidium iodide and analyzed by flow cytometry.

attachment condition, the Hewga-CCS cells began to aggregate and form loose clumps and continued to increase in size; however, they did not form well-rounded structures (Figure 1B).

In chromosomal analysis, a total of 50 metaphase cells from Hewga-CCS were examined by G-banding methods. The following karyotypes were found: 44-47, XX, add(1)(p? $36.1),+3,-5,-6,+7,-9$, add(11)(q13), -12, -16, +19, add (19)(q?13.1), -20, -22, +mar1, +mar2,+mar3 (Additional file 3: Figure S3 and Additional file 4: Table S1). M-FISH analysis revealed 5 recurrent structural chromosomal rearrangements, including $\mathrm{t}(12 ; 22)$ (Figure $1 \mathrm{C}$ and Additional file 5: Table S2).

To verify the presence and investigate the type of EWS-ATF1 chimeric transcripts in Hewga-CCS cells, we performed RT-PCR and direct sequence analyses. RT-PCR with EWS forward primer and ATF1 reverse primers amplified cDNA fragments of the EWS-ATF1 transcript (Figure 1D). Sequencing of the amplified fragments showed that EWS exon 7 was fused with $A T F 1$ exon 5, which was proven to be the type 2 transcript of EWS-ATF1 (Figure 1E) [14].

To determine tumorigenicity, $1 \times 10^{7}$ Hewga-CCS cells were subcutaneously injected into the dorsal flank of nude mice. All animals developed solid tumors at the sites of injection (Additional file 6: Figure S4). Histological analyses showed that xenografts comprised nests or short fascicles of only slightly polymorphous clear cells, and the nuclei were large and round with low mitotic activity. The morphological features were very similar to those observed in the primary tumor. The positive immunoreactivities of S-100 protein, Melan-A, and HMB45 in the Hewga-CCS xenografts were also similar to those of the primary tumor (Figure 2). These results demonstrated that Hewga-CCS harboring the type 2 EWS-ATF1 transcript continuously grew in vitro and developed tumors in nude mice, while retaining a phenotype similar to that of the primary tumor in terms of cell morphology and melanocytic features.

\section{Pazopanib inhibited Hewga-CCS cell growth in vitro}

Recent clinical evidence showing that pazopanib was effective for metastatic STS has been published [16]. However, the sensitivity of CCS to pazopanib remains unknown. To test the effects of pazopanib on the growth of Hewga-CCS cells, these cells were incubated for 24 to $72 \mathrm{~h}$ with pazopanib at concentrations of $0-20 \mu \mathrm{mol} / \mathrm{L}$, following which the number of living cells was counted. A dose-dependent decrease in the number of living Hewga-CCS cells was 

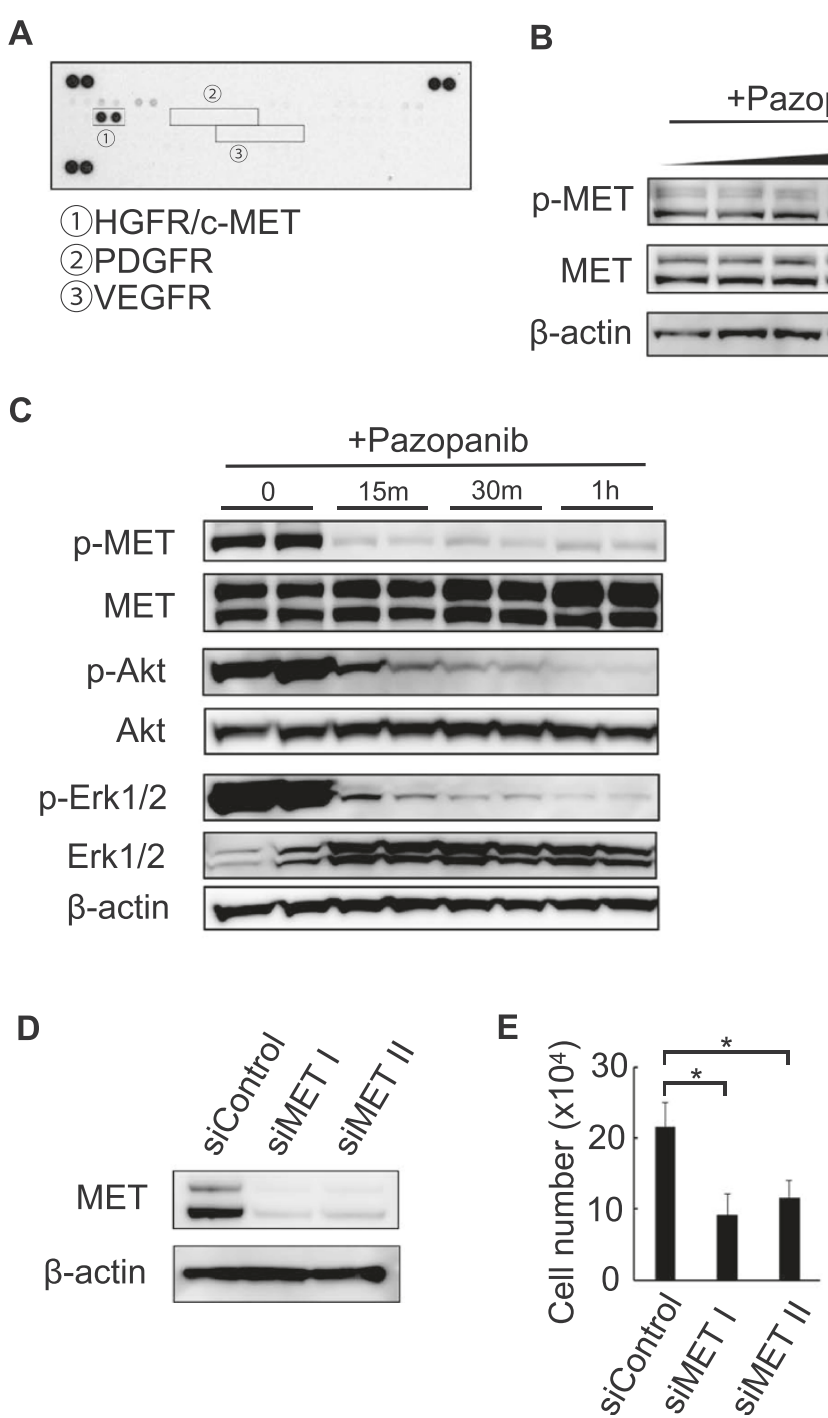

Figure 4 The c-MET pathway as a potential target of pazopanib in Hewga-CCS cells. (A) Phospo-RTK array analysis of Hewga-CCS cells. (B) Western blot analyses of Hewga-CCS cells treated with increasing doses of pazopanib (0, 1, 5, 10, 15, $20 \mu \mathrm{M})$ for 30 min. (C) Western blot analyses of Hewga-CCS cells treated with $30 \mu \mathrm{M}$ of pazopanib. (D) Western blot analyses of Hewga-CCS cells $72 \mathrm{~h}$ after the inhibition of c-MET by siRNAs. (E) Cell counts of Hewga-CCS cells $72 \mathrm{~h}$ after the inhibition of c-MET by siRNAs Bars: SD. ${ }^{*} \mathrm{P}<0.01$.

observed (Figure $3 \mathrm{~A})$. The $\mathrm{IC}_{50}$ value of pazopanib was approximately $8 \mu \mathrm{mol} / \mathrm{L}$ after $72 \mathrm{~h}$ of culture (Figure $3 \mathrm{~B}$ ).

Vehicle or $10 \mu \mathrm{mol} / \mathrm{L}$ of pazopanib was used to perform cell cycle analysis. At $24 \mathrm{~h}$ of culture, an enhanced G0/G1 peak was observed in the pazopanib-treated cells (Figure 3C). No cleaved caspase-3 protein or cleaved polyADP-ribose was detected after culture with pazopanib (data not shown). These data indicated that pazopanib has a direct antiproliferative effect on Hewga-CCS cells in vitro.

The c-MET pathway is a potential target for pazopanib in Hewga-CCS cells

To decipher the signaling pathway relevant to the antitumor effect of pazopanib on Hewga-CCS cells, we used
phospho-RTK array analysis and observed strong activation of the HGF receptor, but not of VEGFR or PDGFR (Figure 4A). Immunoblotting analyses consistently showed c-MET phosphorylation. Interestingly, pazopanib inhibited autophosphorylation of c-MET in a dose-dependent manner, whereas total c-MET remained constant (Figure 4B). We then examined whether pazopanib-mediated c-MET inhibition affected intracellular signaling in Hewga-CCS cells. Decreases in Akt and Erk1/2 phosphorylation occurred concurrently with the decrease in c-MET phosphorylation (Figure 4C). In addition, silencing of c-MET expression by siRNA significantly suppressed the growth of Hewga-CCS cells (Figure 4D, E). To examine whether pazopanib 


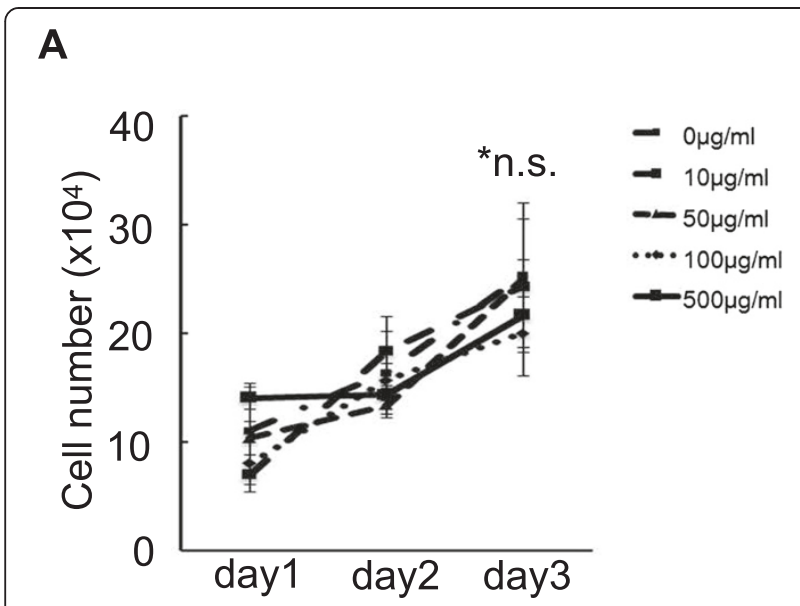

B

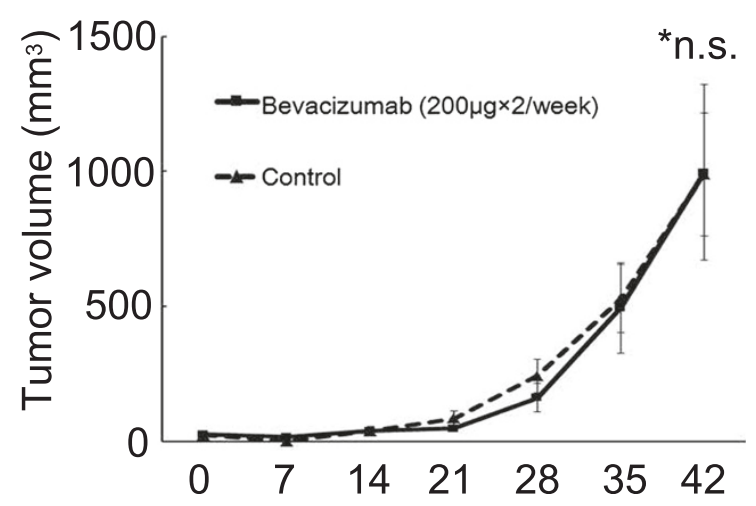

Figure 5 Bevacizumab had no significant effects on Hewga-CCS cell growth. (A) Hewga-CCS cells were cultured in serum-

containing medium in the absence or presence of 10,50,100, and $500 \mu \mathrm{g} / \mathrm{mL}$ of bevacizumab. The cell numbers were counted. Bars: SD. n.s.; not significant. (B) Nude mice were inoculated subcutaneously in the flank with $1 \times 10^{7}$ Hewga-CCS cells. When the tumors reached a palpable size, the mice were treated twice per week with intraperitoneal injection of $200 \mu \mathrm{g}$ of bevacizumab or PBS, following which the tumor size was measured. Bars: SE. n.S.; not significant.

has the similar effects on other sarcoma cell line, we used Asra-Eps [29], which was our established epithelioid sarcoma cell line driven by HGF/c-MET signaling. We found that pazopanib inhibited Asra-Eps cell growth in vitro and autophosphorylation of c-MET in a dosedependent manner (data not shown). These data suggested that pazopanib exerted antitumor effects on Hewga-CCS by abrogating c-MET signaling.

\section{Bevacizumab had no effect on Hewga-CCS cell growth} Next, to investigate the potential role of VEGF signaling in Hewga-CCS, we examined the growth of Hewga-CCS cells treated with bevacizumab, humanized murine monoclonal VEGF antibody [30]. Bevacizumab did not affect the proliferation and survival of Hewga-CCS in vitro (Figure 5A). We also tested the antitumor effects of bevacizumab on the progression of Hewga-CCS xenografts. Treatment with bevacizumab showed no significant impact on tumor growth (Figure 5B). In addition to the phosphor-RTK array findings indicating no VEGFR activation, these results suggested that VEGF signaling was not crucial for Hewga-CCS cell growth and supported our hypothesis that c-MET signaling was a potential target for pazopanib in Hewga-CCS cells.

\section{Pazopanib decreased the tumor growth of Hewga-CCS in a xenograft mouse model by suppressing cell cycle progression}

Lastly, we assessed the in vivo efficacy of pazopanib using a Hewga-CCS xenograft mouse model. Tumor growth in treated mice was significantly delayed compared with that in the vehicle group (Figure 6A). Consistent with the in vitro data, TUNEL assays on tumor sections from treated and control mice showed no significant differences, but Ki-67 staining was significantly decreased in the pazopanib-treated group (Figures 6B-D). We also investigated c-MET activation in Hewga-CCS tumor tissues and found that pazopanib inhibited c-MET phosphorylation in Hewga-CCS xenografts (Figure 6E, Additional file 7: Figure S5). These results demonstrated that pazopanib delayed Hewga-CCS tumor growth by suppressing cell cycle progression, not by inducing tumor cell apoptosis, at least in part through the inhibition of c-MET signaling.

\section{Discussion}

Because of the histological similarities with malignant melanoma, CCS is also known as malignant melanoma of soft parts [31]. However, the genetic findings of the EWS-ATF1 fusion gene support the supposition that CCS and malignant melanoma are 2 distinct entities [13]. To the best of our knowledge, 12 CCS cell lines have been reported in the English literature [17-27], and there are only 4 cell lines that have been shown to possess both tumorigenicity in immunodeficient mice and EWS-ATF1 fusion transcripts (Table 1). Furthermore, there is only 1 cell line (UM-CCS-1) that has the type 2 EWS-ATF1 transcript (Table 1). However, UM-CCS-1 could be passaged only in nude mice. Therefore, HewgaCCS is the first cell line that harbors the type 2 chimeric EWS-ATF1 transcript and can be stably cultured in vitro and xenografted in nude mice.

It has been reported that EWS-ATF1 directly activates the melanocyte transcription factor (MITF) [26], which in turn activates the c-MET gene [32]. Furthermore, 

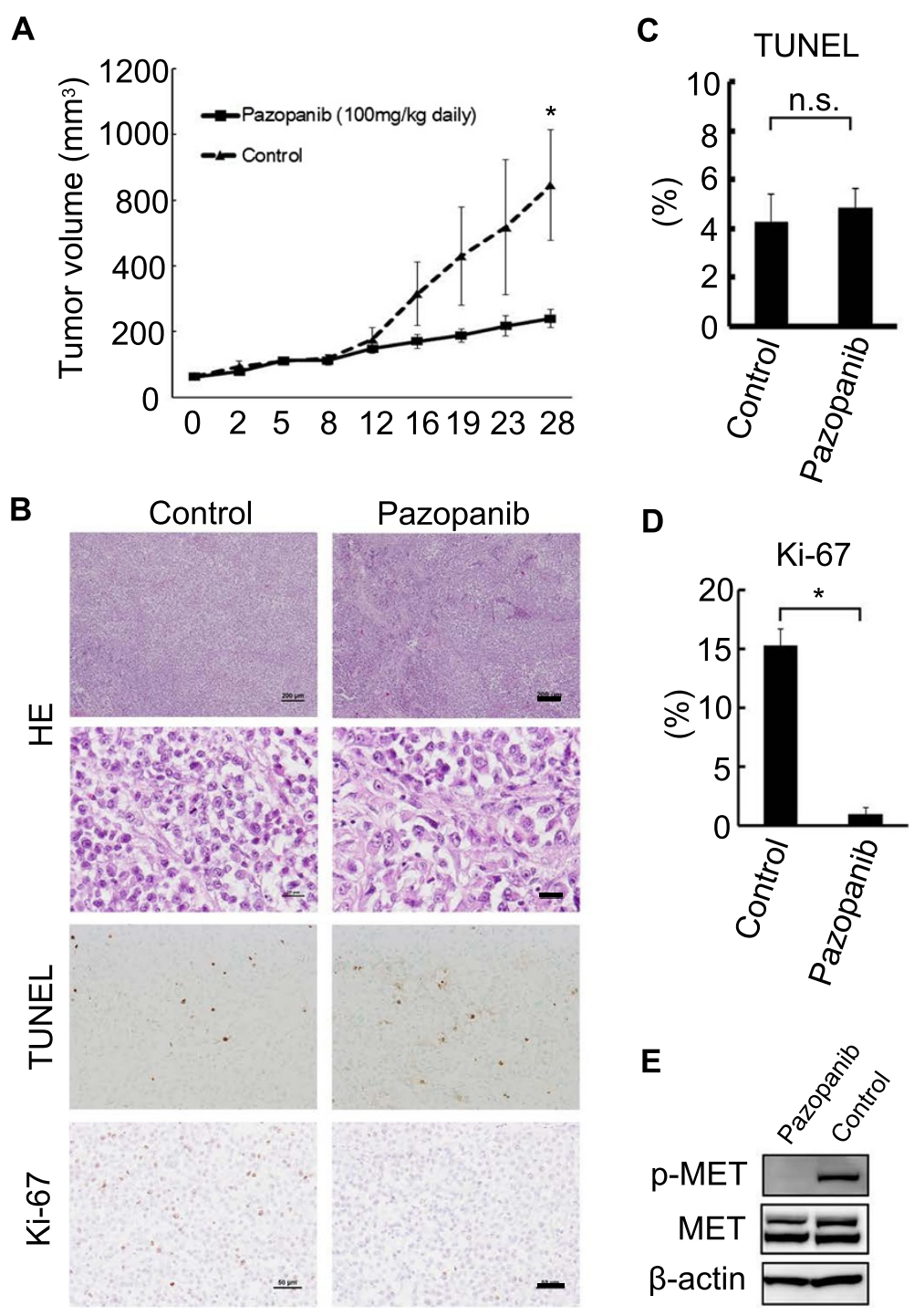

Figure 6 Pazopanib suppressed tumor growth in a Hewga-CCS tumor xenograft model. (A) Nude mice were inoculated subcutaneously in the flank with $1 \times 10^{7} \mathrm{Hewga}-\mathrm{CCS}$ cells. When the tumors reached a palpable size, the mice were treated daily by oral gavage pazopanib $(100 \mathrm{mg} / \mathrm{kg})$ or vehicle control, following which tumor size was measured. Bars: SE. ${ }^{*} \mathrm{P}<0.05$. (B) Representative microscopic images of tumor sections are shown to be stained with hematoxylin/eosin (HE), TUNEL, and Ki-67. Bars in the top rows: $200 \mu \mathrm{m}$. Bars in the second rows: $20 \mu \mathrm{m}$. Bars in the bottom rows: $50 \mu \mathrm{m}$. (C) The TUNEL assay showed no significant difference between pazopanib- and vehicle control-treated xenografts. $\mathrm{n}$. s.; not significant. (D) Ki-67 staining showed significantly suppressed cell cycles in pazopanib-treated xenografts. ${ }^{*} \mathrm{P}<0.05$. (E) Western blot analyses of Hewga-CCS xenografts. Xenografted mice were treated with $100 \mathrm{mg} / \mathrm{kg}$ of pazopanib or vehicle control orally once a day for 1 week, sacrificed $3 \mathrm{~h}$ after final administration, and subjected to Western blot analyses.

c-MET is widely activated in CCS in an autocrine fashion by its ligand HGF, and CCS strongly depends on HGF/c-MET signaling [33,34]. In agreement with previous reports, we identified a robust activation of c-MET in Hewga-CCS cells (Figure 4A). In addition, we found that Hewga-CCS cells secreted higher amounts of HGF and moderate amounts of VEGF into the culture media compared with the amount of SYO-1 (Additional file 8: Figure S6). These results indicated that Hewga-CCS produced autocrine ligand HGF to activate CCS driver kinase c-MET. Therefore, from the context of analyzing drug sensitivity, Hewga-CCS driven by c-MET signaling commonly observed in CCS can be useful for the accelerated development of targeted therapies for CCS.

Pazopanib is approved for the treatment of advanced renal cell carcinoma and advanced STS by the U.S. Food and Drug Administration [16,35]. However, there have only been a few reports that have demonstrated the 
Table 1 Characterization of clear cell sarcoma cell lines

\begin{tabular}{|c|c|c|c|c|}
\hline Cell lines & Age/Sex & Site & Type of EWS-ATF1 & Tumorigenicity \\
\hline SU-CCS1 (1984) & $16 / F$ & heel & 1 & yes \\
\hline HS-MM (1993) & $39 / \mathrm{M}$ & knee & - & yes \\
\hline NCS-1 (1994) & $38 / \mathrm{M}$ & foot & - & yes \\
\hline DTC1 (1995) & - & chest wall & 1 & - \\
\hline MST1 (1996) & $14 / F$ & knee & - & yes \\
\hline Kao (1997) & $9 / F$ & thigh & 1 & yes \\
\hline MP-CCS-SY (2002) & $17 / F$ & ankle & 1 & - \\
\hline GG62 (2002) & $25 / F$ & lower leg & 1 & - \\
\hline MST2 (2004) & $60 / M$ & knee & 1 & - \\
\hline MST3 (2004) & $34 / \mathrm{M}$ & groin & 1 & - \\
\hline CCS292 (2006) & - & - & 1 & yes \\
\hline UM-CCS-1 (2002) & $60 / F$ & thigh & 2 & yes (in vivo only) \\
\hline Hewga-CCS & $34 / F$ & toe & 2 & yes \\
\hline
\end{tabular}

-: Data not described.

molecular mechanism by which pazopanib inhibits the growth of a variety of tumors [15,36-40]. Kumar used a cell-free assay system to show kinase activity of pazopanib and found that pazopanib had an $\mathrm{IC}_{50}$ value of $6 \mu \mathrm{mol} / \mathrm{L}$ for inhibiting c-MET activity [15]. This value was much higher than the $\mathrm{IC}_{50}$ values of $<0.1 \mu \mathrm{mol} / \mathrm{L}$ for pazopanib target kinases, including the VEGFRs, PDGFRs, FGFRs, and c-Kit [15]. Podar demonstrated that pazopanib inhibited multiple myeloma cell growth in vitro by inhibiting VEGF signaling at $\mathrm{IC}_{50}$ values of $10-30 \mu \mathrm{mol} / \mathrm{L}$ [37]. Paesler demonstrated that pazopanib abrogated the survival of chronic lymphocytic leukemia cells at an $\mathrm{IC}_{50}$ of $32.7 \mu \mathrm{mol} / \mathrm{L}$ through VEGF pathway suppression [38]. These studies revealed significant differences in $\mathrm{IC}_{50}$ values for pazopanib between cell growth assays and cell-free assays. A potential explanation for this discrepancy is the possibility that kinase activity may be different between living cell and cell-free conditions. In this study, the $\mathrm{IC}_{50}$ value of pazopanib in terms of Hewga-CCS cell growth was approximately $8 \mu \mathrm{mol} / \mathrm{L}$, and comparable concentrations were reportedly achieved after once-daily administration of $\geq 200 \mathrm{mg}$ pazopanib [41]. It was reported that the combination of pazopanib and lapatinib led to complete inhibition of c-MET by an unknown mechanism, although each of the inhibitors alone had marginal or partial effects [36]. Further, Gotink suggested that low binding affinity of a tyrosine kinase inhibitor to a certain kinase may have a crucial impact on cell signaling, while the same inhibitor with a high binding affinity to another kinase may have no significant effect [42]. We demonstrated the inhibition of c-MET in xenografts treated with pazopanib (Figure 6E). In addition, we showed no significant antitumor effects of bevacizumab in vitro and in vivo (Figure 5). These results indicated that pazopanib delayed xenograft development by direct antitumor activity through the inhibition of c-MET signaling, at least in part.

\section{Conclusions}

We established a novel CCS cell line called Hewga-CCS and developed a xenograft mouse model. We then demonstrated the direct antitumor effects of pazopanib on Hewga-CCS through the inhibition of HGF/c-MET signaling. Because of the rarity of this disease, Hewga-CCS could be a useful tool for interrogating the tumor biology of CCS and developing new therapeutic strategies.

\section{Additional files}

Additional file 1: Figure S1. Clinical course of the patient. A 34-yearold woman with a 3-year history of a slowly growing mass at the $3^{\text {rd }}$ toe of the right foot was referred to our hospital (A). Axial MRI revealed a poorly circumscribed soft tissue mass in the toe, with slightly increased intensity on T1- and T2-weighted images compared with the intensity of muscles (B). While laboratory findings showed no inflammatory reactions, including normal levels of leukocytes $\left(4,310 / \mathrm{mm}^{3}\right)$ and CRP $(0.1 \mathrm{mg} / \mathrm{dl})$, the initial diagnosis was local paronychia because of unclear border of the mass and the presence of erythema around the nail. Because of persistence of the mass despite oral antibiotic medication, an excisional biopsy was performed. Histopathology showed that the tumors comprised clear cells with large nuclei and distinct nucleoli delineated by fibrous septa into well-defined nests and the patient was diagnosed with clear cell sarcoma. A staging FDG-PET scan of the whole body showed a primary mass in the toe as well as several nodules in the right thigh with increased accumulation of FDG, suggesting metastatic spread to regional lymph nodes (C: at presentation, D: 5 months later, E: 8 months later, F: 14 months later). Despite receiving local radiotherapy and three cycles of systemic chemotherapy composed of doxorubicin and ifosfamide, widespread metastatic dissemination to the lymph nodes, bones, skin, spleen, and liver gradually appeared. Twenty-one months after the first presentation, she died because of multiple organ failure. Through the clinical course, the patient has not been exposed to pazopanib. 
Additional file 2: Figure S2. Growth curve of Hewga-CCS cells. Hewga-CCS cells were cultured in DMEM with $10 \%$ FBS. A total of $1 \times 10^{5}$ cells/well were seeded in 6-well plates in triplicate. Cell counts were determined using trypan blue exclusion-based methods. Hewga-CCS cells exhibited logarithmic growth for 8 days, with a doubling time of approximately $44 \mathrm{~h}$ in the DMEM with 10\% FBS.

Additional file 3: Figure S3. A representative G-banded karyotype of the Hewga-CCS cells. The karyotype of the Hewga-CCS cells was 44 47, $X X$, add (1)(p?36.1), +3,-5,-6,+7,-9, add(11)(q13),-12,-16,+19, add(19)(q?13.1),-20,$22,+$ mar1,+mar2,+mar3. The arrows indicate chromosomal abnormalities

Additional file 4: Table S1. Chromosome number and cell number of G-band karyotyping

Additional file 5: Table S2. Chromosome number and cell number of M-FISH analysis.

Additional file 6: Figure S4. Xenografted mouse model. Hewga-CCS cells $\left(1 \times 10^{7}\right)$ were injected subcutaneously into the flanks of 5 -week-old athymic nude mice (BALB/c nu/nu; SLC, Shizuoka, Japan) (A). (B) Tumor growth in vivo. Tumor size was measured with a caliper, and tumor volume was calculated by the formula $\left(a \times b^{2}\right) / 2$

Additional file 7: Figure S5. Immunohistochemical analyses of Hewga-CCS xenografts. Xenografted mice were treated with 100 mg/ $\mathrm{kg}$ of pazopanib or vehicle control orally once a day for 1 week, sacrificed $3 \mathrm{~h}$ after final administration, and subjected to immunohistochemical analyses.

Additional file 8: Figure S6. Secretion of HGF and VEGF from Hewga-CCS cells in vitro. Secretion of HGF and VEGF was quantified by ELISA. Hewga-CCS and the synovial sarcoma cell line SYO-1 was cultured in DMEM with 10\% FBS for $72 \mathrm{~h}$. The supernatants were subjected to ELISA.

\section{Abbreviations}

CCS: Clear cell sarcoma; STS: Soft tissue sarcoma; EWS: Ewing sarcoma gene; ATF1: Activating transcription factor 1; TKl: Tyrosine kinase inhibitor; MMITF: Melanocyte specific-microphthalmia-associated transcription factor; S-100: S100 calcium binding protein; HMB45: Melanoma-associated antigen human melanoma black 45; VEGF: Vascular endothelial growth factor; PDGF: Platelet-derived growth factor; FGF: Fibroblast growth factor; c-Kit: Stem cell factor receptor; M-FISH: Multicolor fluorescence in situ hybridization analysis; RTK: Receptor tyrosine kinase; TUNEL: Terminal deoxyribonucleotidyl transferase (TDT)-mediated dUTP-digoxigenin nick end labeling; siRNAs: Small interfering RNAs; HGF: Hepatocyte growth factor.

\section{Competing interests}

The authors had no potential competing interest related to this study.

\section{Author's contributions}

$\mathrm{HO}$ and NN conceived and designed the study, collected, analyzed, and interpreted the data, wrote the manuscript, and provided final approval. $\Pi$, TW, YI, KH, and NA collected data. Kl collected, analyzed, and interpreted the data. HY provided the study material. All authors read and approved the final manuscript.

\section{Acknowledgments}

We thank Asa Tada and Mari Shinkawa for technical support. We also thank Dr. Ozaki and Dr. Kunisada Okayama University, Japan for SYO-1 cells. This work was supported by the Japan Society for the Promotion of Science, JSPS KAKENHI Grant Number 24592233.

\section{Author details}

'Department of Orthopaedic Surgery, Osaka University Graduate School of Medicine, 2-2 Yamadaoka, Suita, Osaka 565-0871, Japan. ${ }^{2}$ Musculoskeletal Oncology Service, Osaka Medical Center for Cancer and Cardiovascular Diseases, 1-3-3 Nakamichi, Higashinari-ku, Osaka 537-8511, Japan. ${ }^{3}$ Department of Biology, Osaka Medical Center for Cancer and Cardiovascular Diseases, 1-3-3 Nakamichi, Higashinari-ku, Osaka 537-8511, Japan.

Received: 10 February 2014 Accepted: 10 June 2014

Published: 19 June 2014

\section{References}

1. Enzinger FM: Clear-cell sarcoma of tendons and aponeuroses: an analysis of 21 cases. Cancer 1965, 18:1163-1174.

2. Goldblum JR, Flope AL, Weiss SW: Soft Tissue Tumors Showing Melanocytic Differentiation. In Enzinger \& Weiss's Soft Tissue Tumors. 6th edition. Philadelphia: Elsevier; 2013:886-894.

3. Sara AS, Evans HI, Benjamin RS: Malignant melanoma of soft parts (clear cell sarcoma): a study of 17 cases, with emphasis on prognostic factors. Cancer 1990, 65:367-374.

4. El-Naggar AK, Ordonez NG, Sara A, McLemore D, Batsakis JG: Clear cell sarcomas and metastatic soft tissue meranomas. Cancer 1991, 67:2173-2179.

5. Lucas DR, Nascimento AG, Sim FH: Clear cell sarcoma of soft tissues: Mayo Clinic experience with 35 cases. Am J Surg Pathol 1992, 16:1197-1204.

6. Montgomery EA, Meis JM, Ramos AG, Frisman DM, Martz KL: Clear cell sarcoma of tendons and aponuroses: a clinicopathologic study of 58 cases with analysis of prognostic factors. Int J Surg Pathol 1993, 1:89-100

7. Deenik W, Mooi WJ, Rutgers EJ, Peterse JL, Hart AA, Kroon BB: Clear cell sarcoma (malignant melanoma) of soft parts: a clinicopathologic study of 30 cases. Cancer 1999, 86:969-975.

8. Finley JW, Hanypsiak B, Mcgrath B, Kraybill W, Gibbs JF: Clear cell sarcoma: the Roswell Park experience. J Surg Oncol 2001, 77:16-20.

9. Ferrari A, Casanova M, Bisogno G, Mattke A, Meazza C, Gandola L, Sotti G, Cecchetto G, Harms D, Koscielniak E, Treuner J, Carli M: Clear cell sarcoma of tendons and aponeuroses in pediatric patients: a report from the Italian and German Soft Tissue Sarcoma Cooperative Group. Cancer 2002, 94:3269-3276.

10. Takahira T, Oda Y, Tamiya S, Yamamoto H, Kawaguchi K, Kobayashi C, Iwamoto $Y$, Tsuneyoshi M: Alteration of the $\mathrm{p} 16^{\mathrm{INK} 4 a} / \mathrm{p} 14^{\mathrm{ARF}}$ pathway in clear cell sarcoma. Cancer Sci 2004, 95:651-655.

11. Kawai A, Hosono A, Nakayama R, Matsumine A, Matsumoto S, Ueda T, Tsuchiya H, Beppu Y, Morioka H, Yabe H, Japanese Musculoskeletal Oncology Group: Clear cell sarcoma of tendons and aponeuroses: a study of 75 patients. Cancer 2007, 109:109-116.

12. Bridg JA, Sreekantaiah C, Neff JR, Sandberg AA: Chromosomal findings in clear cell sarcoma of tendons and aponeuroses: malignant melanoma of soft parts. Cancer Genet Cytogent 1991, 52:101-106.

13. Zucman J, Delattre O, Desmaze C, Epstein AL, Stenman G, Speleman F, Fletchers CD, Aurias A, Thomas G: EWS and ATF-1 gene fusion induced by $\mathrm{t}(12 ; 22)$ translocation in malignant melanoma of soft parts. Nat Gent 1993, 4:341-345.

14. Panagopoulos I, Mertens F, Debiec-Rychter M, Isaksson M, Limon J, Kardas I, Domanski HA, Sciot R, Perek D, Crnalic S, Larsson O, Mandahl N: Molecular genetic characterization of the EWS/ATF1 fusion gene in clear cell sarcoma of tendons and aponeuroses. Int J Cancer 2002, 99:560-567.

15. Kumar R, Knick VB, Rudolph SK, Johnson JH, Crosby RM, Crouthamel MC, Hopper TM, Miller CG, Harrington LE, Onori JA, Mullin RJ, Gilmer TM, Truesdale AT, Epperly AH, Boloor A, Stafford JA, Luttrell DK, Cheung M: Pharmacokinetic-pharmacodynamic correlation from mouse to human with pazopanib, a multikinase angiogenesis inhibitor with potent antitumor and antiangiogenic activity. Mol Cancer Ther 2007, 6:2012-2021.

16. Van der Graf WT, Blay JY, Chawala SP, Kim DW, Bui-Nguyen B, Casali PG, Schöffski P, Aglietta M, Staddon AP, Beppu Y, Le Cesne A, Gelderblom H, Judson IR, Araki N, Ouali M, Marreaud S, Hodge R, Dewji MR, Coens C, Demetri GD, Fletcher CD, Dei Tos AP, Hohenberger P, EORTC Soft Tissue and Bone Sarcoma Group; PALETTE study group: Pazopanib for metastatic soft-tissue sarcoma (PALLETE): a randomized, doubleblind, placebo-controlled phase 3 trial. Lancet 2012, 379:1879-1886.

17. Epstein AL, Martin AO, Kempson R: Use of a newly established human cell line (SU-CCS-1) to demonstrate the relationship of clear cell sarcoma to malignant melanoma. Cancer Res 1984, 44:1265-1274.

18. Sonobe H, Furihata M, Iwata J, Ohtsuki Y, Mizobuchi H, Yamamoto $H$, Kumano O: Establishment and characterization of a new human clear cell sarcoma cell-line, HS-MM. J Pathol 1993, 169:317-322.

19. Takenouchi T, Ito K, Kazama T, Ito M: Establishment and characterization of a clear-cell sarcoma (malignant melanoma of soft parts) cell line. Arch Dermatol Res 1994, 286:254-260.

20. Brown AD, Lopez-Terrada D, Denny C, Lee KA: Promoters containing ATF-binding sites are de-regulated in cells that express the EWS/ATF1 oncogene. Oncogene 1995, 10:1749-1756.

21. Liao SK, Perng YP, Lee LA, Chang KS, Lai GM, Wong E, Ho YS: Newly established MST-1 tumour cell line and tumour-infiltraing lymphocyte 
culture from a patient with soft tissue melanoma (clear cell sarcoma) and their potential applications to patient immunotherapy. Eur J Cancer 1996, 32A:346-356.

22. Hiraga H, Nojima T, Abe S, Yamashiro K, Yamawaki S, Kaneda K, Nagashima K: Establishment of a new continuous clear cell sarcoma cell line. Morphological and cytogenetic characterization and detection of chimeric EWS/ATF1 transcripts. Virchows Arch 1997, 431:45-51.

23. Moritake $H$, Sugimoto $T$, Asada $Y$, Yoshida MA, Maehara Y, Epstein AL, Kuroda $\mathrm{H}$ : Newly established clear cell sarcoma (malignant melanoma of soft parts) cell line expressing melanoma associated Melan-A antigen and overexpression C-MYC oncogene. Cancer Genet Cytogenet 2002, 135:48-56.

24. Schaefer KL, Wai DH, Poremba C, Korsching E, van Valen F, Ozaki T, Boecker W, Dockhorn-Dworniczak B: Characterization of the malignant melanoma of soft-parts cell line GG-62 by expression analysis using DNA microarrays. Virchows Arch 2002, 440:476-484.

25. Schaefer KL, Brachwitz K, Wai DH, Braun Y, Diallo R, Korsching E, Eisenacher M, Voss R, Van Valen F, Baer C, Selle B, Spahn L, Liao SK, Lee KA, Hogendoorn PC, Reifenberger G, Gabbert HE, Poremba C: Expression profiling of $\mathrm{t}(12 ; 22)$ positive clear cell sarcoma of soft tissue cell lines reveals characteristic up-regulation of potential new marker genes including ERBB3. Cancer Res 2004, 64:3395-3405.

26. Davis IJ, Kim JJ, Ozasolak F, Widlund HR, Rozenblatt-Rosen O, Granter SR, Du J, Fletcher JA, Denny CT, Lessnick SL, Linehan WM, Kung AL, Fisher DE: Oncogenic MITF dysregulation in clear cell sarcoma: defining the MiT family of human cancers. Cancer Cell 2006, 9:473-484.

27. Crnalic S, Panagopoulos I, Boquist L, Mandahl N, Stenling R, Löfvenberg R: Establishment and characterization of a human clear cell sarcoma model in nude mice. Int J Cancer 2002, 101:505-511.

28. Naka N, Takenaka S, Araki N, Miwa T, Hashimoto N, Yoshioka K, Joyama S, Hamada K, Tsukamoto Y, Tomita Y, Ueda T, Yoshikawa H, Itoh K: Synovial Sarcoma Is a stem cell malignancy. Stem Cells 2010, 28:1119-1131.

29. Imura Y, Naka N, Outani H, Yasui H, Takenaka S, Hamada K, Ozaki R, Kaya M, Yoshida K, Morii E, Myoui A, Yoshikawa H: A novel angiomatoid epithelioid sarcoma cell line, Asra-EPS, forming tumors with large cysts containing hemorrhagic fluid in vivo. BMC Res Notes 2013, 6:305.

30. Presta LG, Chen H, O'Connor SJ, Chisholm V, Meng YG, Krummen L, Winkler M, Ferrara N: Humanization of an anti-VEGF monoclonal antibody for the therapy of solid tumors and other disorder. Cancer Res 1997, 57:4593-4599.

31. Chung EB, Enzinger FM: Malignant melanoma of soft parts: a reassessment of clear cell sarcoma. Am J Surg Pathol 1983, 7:405-413.

32. McGill GG, Haq R, Nishimura EK, Fisher DE: c-MET expression is regulated by Mitf in the melanocyte lineage. J Biol Chem 2006, 281:10365-10373.

33. Davis IJ, McFadden A, Zhang Y, Coxon A, Burgess TL, Wagner AJ, Fisher DE: Identification of the receptor tyrosine kinase c-met and its ligand, hepatocyte growth factor, as therapeutic targets in clear cell sarcoma. Cancer Res 2010, 70:639-645.

34. Negri T, Brich S, Conca E, Bozzi F, Orsenigo M, Stacchiotti S, Alberghini M, Mauro V, Gronchi A, Dusio GF, Pelosi G, Picci P, Casali PG, Pierotti MA, Pilotti S: Receptor tyrosine kinase pathway analysis sheds light on similarities between clear-cell sarcoma and metastatic melanoma. Genes Chromosomes Cancer 2012, 51:111-126.

35. Sternberg C, Davis I, Mardiak J, Szczylik C, Lee E, Wagstaff J, Barrios CH, Salman P, Gladkov OA, Kavina A, Zarbá JJ, Chen M, McCann L, Pandite L, Roychowdhury DF, Hawkins RE: Pazopanib in locally advanced or metastatic renal cell carcinoma: results of randomized phase III trial. J Clin Oncol 2010, 28:1061-1068.

36. Olaussen KA, Commo F, Tailler M, Lacroix L, Vitale I, Raza SQ, Richon C, Dessen P, Lazar V, Soria JC, Kroemer G: Synergistic proapoptotic effects of the two tyrosine kinase inhibitors pazopanib and lapatinib on multiple carcinoma cell lines. Oncogene 2009, 28:4349-4260.

37. Podar K, Tonon G, Sattler M, Tai YT, Legouill S, Yasui H, Ishitsuka K, Kumar S, Kumar R, Pandite LN, Hideshima T, Chauhan D, Anderson KC: The smallmolecule VEGF receptor inhibitor pazopanib (GW786034B) targets both tumor and endothelial cells in multiple myeloma. Proc Natl Acad Sci U S A 2006, 103:19478-19483.

38. Paesler J, Gehrke I, Gandhirajan RK, Filipovich A, Hertweck M, Erdfelder F, Uhrmacher S, Poll-Wolbeck SJ, Hallek M, Kreuzer KA: The vascular endothelial growth factor receptor tyrosine kinase inhibitors vatalanib and pazopanib potently induce apoptosis in chronic lymphocytic leukemia cells in vitro and in vivo. Clin Cancer Res 2010, 16:3390-3398.

39. Gril B, Palmieri D, Qian Y, Smart D, lleva L, Liewehr DJ, Steinberg SM, Steeg PS: Pazopanib reveals a role for tumor cell B-Raf in the prevention of HER2+ breast cancer brain metastasis. Clin Cancer Res 2011, 17:142-153.

40. Hosaka S, Horiuchi K, Yoda M, Nakayama R, Tohmonda T, Susa M, Nakamura M, Chiba K, Toyama Y, Morioka H: A novel multi-kinase inhibitor pazopanib suppresses growth of synovial sarcoma cells through inhibition of the PI3K-AKT pathway. J Orthop Res 2012, 30:1493-1498.

41. Hurwitz H, Doulati A, Savage S, Savage S, Suttle AB, Gibson DM, Hodge JP, Merkle EM, Pandite L: Phase I trial of pazopanib in patients with advanced cancer. Clin Cancer Res 2009, 15:4220-4227.

42. Gotink KJ, Verheul HMW: Anti-angiogenic tyrosine kinase inhibitors: what is their mechanism of action? Angiogenesis 2010, 13:1-14.

\section{doi:10.1186/1471-2407-14-455}

Cite this article as: Outani et al:: Establishment of a novel clear cell sarcoma cell line (Hewga-CCS), and investigation of the antitumor effects of pazopanib on Hewga-CCS. BMC Cancer 2014 14:455.

\section{Submit your next manuscript to BioMed Central and take full advantage of:}

- Convenient online submission

- Thorough peer review

- No space constraints or color figure charges

- Immediate publication on acceptance

- Inclusion in PubMed, CAS, Scopus and Google Scholar

- Research which is freely available for redistribution 